THE POLITICS OF INEQUALITY 


\section{RESEARCH IN POLITICAL SOCIOLOGY}

\section{Series Editor: Barbara Wejnert}

\section{Recent Volumes:}

$\begin{array}{ll}\text { Volumes 1-3: } & \text { Richard G. Braungart } \\ \text { Volume 4: } & \text { Richard G. Braungart and Margaret M. Braungart } \\ \text { Volumes 5-8: } & \text { Philo C. Wasburn } \\ \text { Volume 9: } & \text { Betty A. Dobratz, Lisa K. Waldner, and Timothy Buzzell } \\ \text { Volumes 10-11: } & \text { Betty A. Dobratz, Timothy Buzzell, and Lisa K. Waldner } \\ \text { Volume 12: } & \text { Betty A. Dobratz, Lisa K. Waldner, and Timothy Buzzell } \\ \text { Volume 13: } & \text { Lisa K. Waldner, Betty A. Dobratz, and Timothy Buzzell } \\ \text { Volumes 14-17: } & \text { Harland Prechel } \\ \text { Volumes 18-21: } & \text { Barbara Wejnert } \\ \text { Volume 22: } & \text { Dwayne Woods and Barbara Wejnert } \\ \text { Volume 23: } & \text { Eunice Rodriguez and Barbara Wejnert } \\ \text { Volume 24: } & \text { Barbara Wejnert and Paolo Parigi } \\ \text { Volume 25: } & \text { Ram Alagan and Seela Aladuwaka } \\ \text { Volume 26: } & \text { Tim Bartley } \\ \text { Volume 27: } & \text { Francesco Duina }\end{array}$




\section{EDITORIAL ADVISORY BOARD}

\author{
Patrick Akard \\ Paul Almeida \\ Robert Antonio \\ Alessandro Bonanno \\ Barbara Brents \\ David Brown \\ Kathleen Kost \\ Rhonda Levine \\ John Markoff \\ Scott McNall \\ Susan Olzak \\ Harland Prechel \\ Adam Przeworski \\ William Roy \\ David A. Smith \\ Henry Taylor
}

\author{
Kansas State University, USA \\ University of California Merced, USA \\ University of Kansas, USA \\ Sam Houston State University, USA \\ University of Nevada Las Vegas, USA \\ Cornell University, USA \\ University at Buffalo, USA \\ Colgate University, USA \\ University of Pittsburgh, USA \\ California State University Chico, USA \\ Stanford University, USA \\ Texas A\&M University, USA \\ New York University, USA \\ University of California Los Angeles, USA \\ University of California Irvine, USA \\ University at Buffalo, USA
}


This page intentionally left blank 
RESEARCH IN POLITICAL SOCIOLOGY VOLUME 28

\title{
THE POLITICS OF INEQUALITY
}

\author{
EDITED BY \\ DAVID PETTINICCHIO
}

University of Toronto, Canada

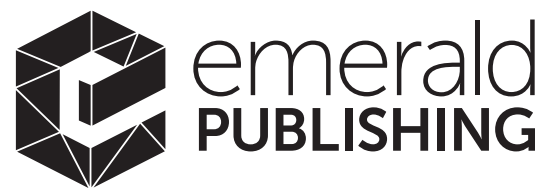

United Kingdom - North America - Japan India - Malaysia - China 
Emerald Publishing Limited

Howard House, Wagon Lane, Bingley BD16 1WA, UK

First edition 2021

Copyright $\odot 2021$ by Emerald Publishing Limited

Reprints and permissions service

Contact: permissions@emeraldinsight.com

No part of this book may be reproduced, stored in a retrieval system, transmitted in any form or by any means electronic, mechanical, photocopying, recording or otherwise without either the prior written permission of the publisher or a licence permitting restricted copying issued in the UK by The Copyright Licensing Agency and in the USA by The Copyright Clearance Center. Any opinions expressed in the chapters are those of the authors. Whilst Emerald makes every effort to ensure the quality and accuracy of its content, Emerald makes no representation implied or otherwise, as to the chapters' suitability and application and disclaims any warranties, express or implied, to their use.

\section{British Library Cataloguing in Publication Data}

A catalogue record for this book is available from the British Library

ISBN: 978-1-83909-363-0 (Print)

ISBN: 978-1-83909-362-3 (Online)

ISBN: 978-1-83909-364-7 (Epub)

ISSN: 0895-9935 (Series)

\section{ISOQAR certified}

Management System,

awarded to Emerald

for adherence to

Environmental

standard

ISOQAR

ISO 14001:2004. 


\section{CONTENTS}

About the Contributors ix

List of Contributors $x v$

Foreword xvii

Acknowledgments xix

PART 1 MAKING INEQUALITY PART OF THE POLITICAL AND POLICY AGENDA

How did Inequality Gain Such Prominence on the Democratic Party Agenda?

Keith Gunnar Bentele

Coalitions that Clash: California's Climate Leadership and the Perpetuation of Environmental Inequality

Joshua A. Basseches, Kaitlyn Rubinstein and Sarah M. Kulaga

\section{PART 2 THE POLITICS OF WELFARE STATE RETRENCHMENT}

Welfare State Recalibration in France and Germany: What Role Do Polarization and Inequalities in People's Attitudes Toward Social Policies Play?

Agnes Blome

Stones versus Routines: Students and Politicians in Higher Education Tuition Policy

Didem Türkoğlu

Welfare, Punishment, and Social Marginality: Understanding the Connections

Marco Brydolf-Horwitz and Katherine Beckett 


\section{PART 3 THE POLITICAL, SOCIAL, AND \\ ECONOMIC IMPACTS OF INEQUALITY ON \\ VULNERABLE GROUPS}

Crises of Social Reproduction among Women of Color: The State and Local Politics of Inequality within Neoliberal Capitalism

Julisa McCoy, Jessica Moronez, Evelyn Pruneda and Ellen Reese

The Persistent Challenge of HIV and Black MSM in the American South: Racial Inequality and the LGBTQ Community 135 Ravi K. Perry and Aaron D. Camp

From Diaspora Mobilization to Immigrant Resistance: Comparing Syrian and Yemeni Mobilization against Inequality at Home and Abroad

Dana M. Moss

\section{PART 4 MOBILIZING AGAINST INEQUALITY}

Occupying Against Inequality

Jacquelien van Stekelenburg and Teodora Gaidyte

Moral Economies, Mobilization, and Inequality: The Case of the 2018 US Teachers' Strikes

Eric Blanc and Barry Eidlin

Living Down to Expectations: Age Inequality and Youth Activism 215 Thomas V. Maher and Jennifer Earl

Creative Disappointment: How Movements for Democracy:

Spawn Movements for Even More Democracy

John Markoff, Hillary Lazar and Jackie Smith 


\section{ABOUT THE CONTRIBUTORS}

Joshua A. Basseches is a Postdoctoral Research Fellow at the University of Michigan's Ford School of Public Policy. He is a political and environmental sociologist whose research investigates the politics of state-level climate and renewable energy policy in the United States. His past work has been published in Mobilization: An International Quarterly. He co-chairs the State Politics Working Group of the Climate Social Science Network.

Katherine Beckett is Chair and Professor of the Department of Law, Societies, and Justice and S. Frank Miyamoto Professor in the Department of Sociology at the University of Washington.

Keith Gunnar Bentele is an Associate Research Professor with the Southwest Institute of Research on Women (SIROW) at the University of Arizona, and holds a PhD in Sociology. His research has examined the processes shaping the passage of various types of legislation (e.g., state-level voter access and abortion restrictions) with special attention to the roles of social movements and partisan control.

Eric Blanc is a PhD candidate in Sociology at New York University. His research focuses on labor, social movements, political parties, and digital technology. He is the author of Red State Revolt: The Teachers' Strike Wave and Working-Class Politics (Verso, 2019) and Revolutionary Social Democracy: Working-Class Politics Across the Russian Empire (1881-1917) (Brill, 2021).

Dr Agnes Blome is currently Guest Professor for Comparative Politics at the Otto-Suhr Institute of Political Science (OSI) at Free University Berlin. At the OSI, she teaches classes on Comparative Social Policy, Comparative Political Institutions, and Gender and Politics. Before joining the OSI, she was senior research fellow at the WZB Berlin Social Science Research Center. She is the author of The Politics of Work-Family Policy Reforms in Germany and Italy (2017, Routledge). Her work appeared in Comparative Politics, Socio-Economic Review, Journal of Social Policy, and Parliamentary Affairs. She is presently studying social policy responsiveness, the politics of care, and the causes and consequences of gender inequalities in political representation.

Marco Brydolf-Horwitz is a PhD Student and Graduate Instructor in the Department of Sociology at the University of Washington.

Aaron D. Camp is a $\mathrm{PhD}$ Candidate in Social Policy at Brandeis University. He received an MSW from Boston University, of Boston MA, in 2012 and a BSW 
from Western Carolina University, Cullowhee NC, in 2009. A recipient of the Robert Wood Johnson Foundation Health Policy Research Scholars fellowship, Aaron's research interests include education inequality, the culture of poverty, social movements, LGBTQ rights, community network systems, syndemics, and health policy.

Jennifer Earl is a Professor of Sociology and (by courtesy) Government and Public Policy at the University of Arizona. Her research focuses on social movements, information technologies, and the sociology of law, with research emphases on youth activism, Internet activism, social movement repression, and legal change. She is the recipient of a National Science Foundation CAREER Award for research from 2006 to 2011 on Web activism, was a member of the MacArthur Research Network on Youth and Participatory Politics, and coauthored with Katrina Kimport, Digitally Enabled Social Change.

Barry Eidlin is an Assistant Professor of Sociology at McGill University. He is a Comparative Historical Sociologist interested in the study of class, politics, social movements, and social change. His book, Labor and the Class Idea in the United States and Canada, was published by Cambridge University Press in 2018. Other research has been published in top peer-reviewed journals including the American Sociological Review, while writing for broader audiences has appeared in the Washington Post and Jacobin, among other venues. He also comments regularly in various media outlets on labor politics and policy.

Teodora Gaidyte teaches at Leiden University, program of International Studies. Her research interests lie in political participation and social movements, social and political trust, democracy, inequality. She studied political science in Vilnius, Lithuania, before she moved to the Netherlands where she obtained her PhD. Her $\mathrm{PhD}$ research investigated how social trust enhances political participation in Western and Eastern Europe. Soon after, she joined the POLPART project ("How citizens try to influence politics, and why? International comparisons of movement and party politics") as a postdoctoral researcher at the Sociology department of the Vrije Universiteit Amsterdam, where with her colleagues she collected and analyzed cross-national data on different forms of political participation. Teodora has published in such journals as Government and Opposition and Political Behavior.

Sarah M. Kulaga is a senior at Northwestern University studying Legal Studies and Theater. After graduation, she plans to attend law school and pursue a career in public service.

Hillary Lazar is a Doctoral Candidate in Sociology at the University of Pittsburgh and holds an MA in History from San Francisco State University. Her research focuses on social movement evaluation, the politics of emotions, and contemporary anarchism. Her work appears in Perspectives on Anarchist Theory, Anarchism: A Conceptual Approach, and Socialism and Democracy. She is a 
member of the Institute for Anarchist Studies' Speakers Bureau and part of the Perspectives editorial collective.

Thomas V. Maher is an Assistant Professor at Clemson University. His research focuses on the intersection between social movements, organizations, and political sociology. He is primarily interested in how social movements and other noninstitutional actors create change, who participates in these efforts, and how states and organizations sustain the status quo. He has published work on these issues in outlets such as Mobilization, American Sociological Review, and the Journal of Peace Research.

John Markoff is Distinguished University Professor of Sociology at the University of Pittsburgh. His books include Social Movements for Global Democracy, Social Movements and World-System Transformation (coedited with Jackie Smith, Michael Goodhart, and Patrick Manning), Economists in the Americas: Convergence, Divergence, and Connection (coedited with Verónica Montecinos), Waves of Democracy: Social Movements and Political Change and The Abolition of Feudalism: Peasants, Lords, and Legislators in the French Revolution. He is currently researching social movements for local democracy in Andalusia since the middle of the nineteenth century.

Julisa McCoy received her PhD in Sociology from the University of California, Riverside, where she is employed as a Lecturer. Her research and teaching interests include gender, race-ethnicity, and class inequalities; reproductive health and politics; public health and social policy; Chicanx/Latinx studies; and social movements. Her research on cutbacks and restrictions to family planning programs in the US was funded by the National Science Foundation's Graduate Research Fellowship Program (2014) and the University of California Consortium on Social Science and Law Fellowship (2017), and her work has appeared in various publications, including The Handbook on Gender and Social Policy (2018), The Oxford Handbook on Women's Social Movement Activism (2017), and Social Service Review (2015).

Jessica Moronez received her PhD in Sociology from the University of California, Riverside. She is a faculty member in the School of Social Sciences and Art at College of the Desert. Her research and teaching interests include families, gender, race/ethnicity, criminology, and sociological research methods. Her research has appeared in Sage Research Methods Cases.

Dana M. Moss, PhD, is an Assistant Professor in the Department of Sociology at the University of Notre Dame. Her research focuses on resistance against authoritarianism, transnational activism, diasporas, and the Middle Eastern region. Her forthcoming book, The Arab Spring Abroad (Cambridge University Press), investigates diaspora activism for the 2011 Arab Spring revolutions in Libya, Syria, and Yemen. Her work has been published in venues such as the American Sociological Review, Social Forces, Social Problems, Mobilization: An International Journal, and Comparative Migration Studies. 
Perry also served as a member of the Board of Directors and Affiliate Equity Officer for the ACLU of Mississippi and was also one of the first openly gay branch presidents of color in the history of the NAACP in Worcester, Massachusetts.

Dr Ravi K. Perry joined the Department of Political Science at Howard University in August 2019 as Chair and Professor. Dr. Perry holds a BA from the University of Michigan and a MA and PhD from Brown University, each in Political Science. He is an expert on Black politics, minority representation, urban politics, public policy, and LGBT candidates of color.

Evelyn Pruneda is a PhD candidate in Sociology at the University of California, Riverside. Her research interests include labor studies, environmental sociology, critical race and gender studies, and social movements. Her dissertation uses a feminist intersectional framework to examine how race, gender, and citizenship status interact with spatial politics and inequalities to shape the working and living conditions of women farmworkers in rural California.

Ellen Reese is Professor of Sociology and Chair of Labor Studies at the University of California, Riverside. Her research focuses on gender, race, and class, welfare state development, social and labor movements, poverty, and work. She is author of They Say Cutback; We Say Fight Back! Welfare Activism in an Era of Retrenchment (2011, American Sociological Association's Rose Series/ Russell Sage) and Backlash Against Welfare Mothers: Past and Present (2005, University of California Press) and coeditor of The Cost of Free Shipping: Amazon in the Global Economy (2020, Pluto Press).

Kaitlyn Rubinstein is completing her BA in the Department of Sociology at Northwestern University with minors in Legal Studies and Native American and Indigenous Studies. Rubinstein's current research interests span states, empires, settler colonialism, race, and constitutional law within the Americas.

Jackie Smith is a Professor of Sociology at the University of Pittsburgh. Her books include Social Movements for Global Democracy, Social Movements and World-System Transformation (coedited with Michael Goodhart, Patrick Manning, and John Markoff), Social Movements in the World-System: The Politics of Crisis and Transformation (with Dawn Wiest), and Global Democracy and the World Social Forums (with multiple collaborators). She currently serves as coordinator of Pittsburgh's Human Rights City Alliance and serves on the steering committee of the US Human Rights Cities Alliance.

Didem Türkoğlu is a Postdoctoral Associate in the Division of Social Science at New York University-Abu Dhabi. Her research interests focus on political sociology, social movements, and studies of social inequalities. In her current book project, she conducts a comparative analysis of higher education policies and the protests against tuition hikes over the last two decades in 34 OECD countries with a special focus on England, Germany, Turkey, and the United States. She highlights the impact of alliances between oppositional groups and 
parties on policy outcomes. In addition, she works on the impact of COVID-19 policies on collective action and social inequalities in Turkey and Brazil. Her articles have appeared in Mobilization, Current Sociology, Social Media + Society, Sociology Compass, and Journal of Democracy.

Jacquelien van Stekelenburg holds a Chair on Social Change and Conflict at the Sociology Department of the VU University Amsterdam. Her research interests focus on moderate and radical protest. With a background in social psychology, she combines a social psychological approach with sociological insights. She conducted an international comparative study on street demonstrations with Klandermans (VU University Amsterdam) and Walgrave (Antwerpen University) funded by the European-Science-Foundation entitled Caught in the Act of Protest: Contextualized Contestation and a study on emerging networks and feelings of belonging funded by the Dutch Royal Academy of Science entitled The evolution of collective action in emerging neighbourhoods. Currently she is involved in Determinants of 'Mobilisation' at Home and Abroad: Analysing the Micro-Foundations of Out-Migration \& Mass Protest. 
This page intentionally left blank 


\section{LIST OF CONTRIBUTORS}

\begin{tabular}{|c|c|}
\hline Joshua A. Basseches & University of Michigan, USA \\
\hline Katherine Beckett & University of Washington, USA \\
\hline Keith Gunnar Bentele & $\begin{array}{l}\text { Southwest Institute for Research on Women, } \\
\text { University of Arizona, USA }\end{array}$ \\
\hline Eric Blanc & $\begin{array}{l}\text { Department of Sociology, New York University, } \\
\text { USA }\end{array}$ \\
\hline Agnes Blome & $\begin{array}{l}\text { Guest Professor for Comparative Politics at Free } \\
\text { University Berlin, Germany }\end{array}$ \\
\hline Marco Brydolf-Horwitz & University of Washington, USA \\
\hline Aaron D. Camp & $\begin{array}{l}\text { The Heller School for Social Policy and Management, } \\
\text { Brandeis University, USA }\end{array}$ \\
\hline Jennifer Earl & University of Arizona, USA \\
\hline Barry Eidlin & $\begin{array}{l}\text { Assistant Professor of Sociology, McGill University, } \\
\text { Canada }\end{array}$ \\
\hline Teodora Gaidyte & $\begin{array}{l}\text { Leiden University, Faculty of Humanities, } \\
\text { International Studies, Netherlands }\end{array}$ \\
\hline Sarah M. Kulaga & Northwestern University, USA \\
\hline Hillary Lazar & University of Pittsburgh, USA \\
\hline Thomas V. Maher & Clemson University, USA \\
\hline John Markoff & $\begin{array}{l}\text { Distinguished University Professor of Sociology at } \\
\text { the University of Pittsburgh, USA }\end{array}$ \\
\hline Julisa McCoy & $\begin{array}{l}\text { Department of Sociology, University of California, } \\
\text { Riverside, USA }\end{array}$ \\
\hline Jessica Moronez & Department of Sociology, College of the Desert, USA \\
\hline Dana M. Moss & University of Notre Dame, USA \\
\hline Ravi K. Perry & $\begin{array}{l}\text { Department of Political Science at Howard } \\
\text { University, USA }\end{array}$ \\
\hline Evelyn Pruneda & $\begin{array}{l}\text { Department of Sociology, University of California, } \\
\text { Riverside, USA }\end{array}$ \\
\hline Ellen Reese & $\begin{array}{l}\text { Department of Sociology, University of California, } \\
\text { Riverside, USA }\end{array}$ \\
\hline Kaitlyn Rubinstein & Northwestern University, USA \\
\hline
\end{tabular}


Jackie Smith

Didem Türkoğlu

Jacquelien van

Stekelenburg
Professor of Sociology at the University of Pittsburgh, USA

New York University Abu Dhabi, Division of Social Science Postdoctoral Associate, UAE

Department of the VU-University, Amsterdam, Netherlands 


\section{FOREWORD}

When I proposed the theme "Politics of Inequality," we were living in very different times. Nevertheless, the COVID-19 pandemic - an exogenous shock to structures and systems - has shined light on extant disadvantages and inequalities as well as cracks and fault lines in policies meant to mitigate inequality.

I cannot think of a better time to talk about the cultural and institutional dimensions of inequality - especially the interplay between these arrangements that perpetuate unequal outcomes in a variety of domains - from work, to education, to health, to climate change, to criminal justice. Equally important to political sociologists is how inequality is challenged via both institutional and extrainstitutional means. Inherent in this volume are recurring subthemes of power, elites, agenda setting, neoliberalism, capitalism, collective action and activism. Contributors to The Politics of Inequality address core issues and concerns in political sociology using a variety of theoretical frameworks and methodological tools.

The volume begins with a discussion about how issues of inequality make it onto the policy agenda. Keith Bentele's chapter directly engages with how Democratic and Republican Party politics coupled with the rise of the Occupy Wall Street movement shaped the politics of inequality. Specifically, he examines how antiinequality positions were woven into mainstream Democratic partisan identity. Similarly, Joshua Basseches and co-authors' piece analyzes the political struggles in California when it comes to climate change, particularly the interplay between policymakers, interest groups, activists, and the business community. They show how California became a "climate change leader" by adopting an approach that relies heavily on market-oriented, neoliberal logics.

The next section of the volume focuses on the politics of welfare state retrenchment - an area that has received considerable attention by sociologists and political scientists over the years. Agnes Blome analyzes the role of public attitudes, especially polarization, on the timing and differing approaches to welfare state reforms in France and Germany. Didem Türkoğlu investigates a specific case of welfare state retrenchment: university tuition. Türkoğlu shows how media in Turkey and Germany covered protests that led right-wing governments in both countries to ultimately abandon their efforts in implementing tuition. Marco Brydolf-Horwitz and Katherine Beckett turn to the interconnected ways in which welfare and punishment serve to govern poor and marginalized peoples. They suggest a continuum of state management where marginalized peoples are subjected to varying degrees of support, surveillance, and sanction. 
The third section expands on the ways in which inequality affects already vulnerable and marginalized groups. Julisa McCoy, Jessica Moronez, Evelyn Pruneda, and Ellen Reese use an intersectional feminist lens to examine the impacts of neoliberal policy trends in the United States when it comes to family planning, public infrastructure, and criminal justice particularly on women of color. Ravi Perry and Aaron Camp shed light on the intersections of race, sexual identity, and health status in shaping inequalities both within and outside of the LGBTQ community. Perry and Camp point to how racism, social and political exclusion, and barriers in accessing health care further marginalize HIV+ Black MSM in the Southern United States. Dana Moss sheds light on how diaspora mobilization facilitates immigrant voice and visibility especially in a context of "a war against immigrants and refugees" in democratic countries worldwide. More specifically, Moss focuses on different approaches between Syrian and Yemeni diaspora mobilization and their impact on host-country discrimination.

Expanding on the theme of collective action and mobilization, the volume concludes with a discussion of the ways in which everyday citizens challenge inequality. In "Occupying Against Inequality," Jacquelien van Stekelenburg and Teodora Gaidyte compare Occupy protests with other contemporaneous antiausterity protests. Although protests in both movements targeted stark inequality following the financial meltdown, they note key differences among them, that Occupiers were much less involved in formal organizations and more dissatisfied with democracy. Eric Blanc and Barry Eidlin use the 2018 teachers' strike wave to pinpoint mechanisms associated with how unions shape moral economies. As they demonstrate, strikes helped reshape individuals' understandings of educational and economic inequality. In their chapter, Thomas Maher and Jennifer Earl investigate age inequality in political participation and the role generalized expectations that youth are "not old enough" to engage politically have on activism. Concluding the volume, John Markoff, Hillary Lazar, and Jackie Smith examine inequalities within democratic movements and how activist disappointments lead to efforts to change movement organizations. They focus specifically on transnational activism that links social justice with environmental concerns and the Occupy Movement.

David Pettinicchio 


\section{ACKNOWLEDGMENTS}

I would like to, above all, acknowledge the tremendous work of our authors who developed fantastic manuscripts and excellent contributions to political sociology in the midst of a global pandemic. I also want to thank our many reviewers who provided thoughtful and insightful comments on each manuscript, as well as members of the Research in Political Sociology editorial board. I want to thank Barbara Wejnert for first, agreeing that the politics of inequality is an important topic to address in the series and second, for providing guidance on the editorial process along the way. Finally, I want to thank the editorial team at Emerald for their help throughout the process and especially in finalizing the volume.

David Pettinicchio 